\title{
Transgenic Tomato Plants Expressing Satellite RNA Are Tolerant to Some Strains of Cucumber Mosaic Virus
}

\author{
P.B. McGarvey and M.S. Montasser \\ Department of Botany, University of Maryland, College Park, MD 20742
}

\author{
J.M. Kaper ${ }^{1}$ \\ Molecular Plant Pathology Laboratory, Agricultural Research Service, U.S. Department of Agriculture, \\ Beltsville, MD 20705
}

Additional index words. CMV, Lycopersicon esculentum, virus resistance

\begin{abstract}
Transgenic tomato plants (Lycopersicon esculentum Mill.) expressing cucumber mosaic virus (CMV) satellite RNA fused to a gene for $\beta$-glucuronidase were produced using Agrobacterium-mediated transformation. The $R_{1}$ progeny of self-crossed $R_{0}$ plants were challenge-inoculated with virion or RNA preparations of CMV or tomato aspermy virus (TAV). The transgenic plants challenged with CMV-1 showed mild disease symptoms in the first 2 weeks postchallenge followed by a decrease in symptoms, resulting in little difference between the transgenic and uninfected control group by the fourth week. Enzyme-linked immunosorbent assay results showed about a 10-fold decrease in virus accumulation in the transgenic plants compared to controls. Tolerance was evident only in plants that contained the recombinant insert and produced mature unit-length satellite RNA after CMV infection. Plants challenged with TAV showed no significant tolerance to virus-induced symptoms.
\end{abstract}

Cucumber mosaic virus (CMV) has been identified as one of the most economically important plant viruses in field-grown vegetable crops worldwide (Tomlinson, 1987). Outbreaks of diseases incited by CMV have caused large losses in tomato and pepper crops in several Mediterranean (Gallitelli et al., 1988; Jorda et al., 1992; Marrou and Duteil, 1974) and Asian countries (Sayama et al., 1993; Tien and $\mathrm{Wu}, 1991)$. In the United States, high incidences of CMV have been reported in several states (Daniels and Campbell, 1992; Davis and Shifriss, 1983; Gonsalves et al., 1982; Kearney et al., 1990).

Some strains of CMV contain a small linear satellite RNA, which depends on its helper virus for replication and spread. CMV satellite RNAs show no significant sequence homology to the viral genomic RNAs and seem to be unnecessary for any known viral functions (Collmer and Howell, 1992; Kaper and Collmer, 1988; Roossinck et al., 1992). In most cases, satellite RNAs attenuate CMV symptoms and reduce the amount of infectious virus found in plant tissues. However, a few satellite variants can induce new disease symptoms when combined with CMV in an appropriate host plant and have been implicated as the main etiological agent in several CMV epidemics (Jorda et al., 1992; Kaper et al., 1990a).

The attenuating properties of some satellite RNAs can be exploited to control viral diseases by preinoculating crops with an attenuating satellite RNA variant combined with virus. This technique can effectively protect against CMV disease in the field (Gallitelli et al., 1991; Montasser et al., 1991; Sayama et al., 1993; Tien and Wu, 1991; Tien et al., 1987). Transgenic tobacco plants expressing an endogenous CMV satellite RNA transcript have also been shown to be tolerant to mechanical and aphid-borne CMV

Received for publication 28 Apr. 1993. Accepted for publication 6 July 1993. This research was supported in part by USAID project 936-4136. Mention of a commercial company or specific equipment does not constitute its endorsement by the authors or the USDA over similar equipment or companies not named. The cost of publishing this paper was defrayed in part by the payment of page charges. Under postal regulations, this paper therefore must be hereby marked advertisement solely to indicate this fact.

'To whom reprint requests should be addressed. infections (Baulcombe et al., 1986; Harrison et al., 1987; Jacquemond et al., 1988; Masuta et al., 1989). We have previously shown that transgenic tomato plants expressing a necrosis-inducing satellite RNA variant do not develop lethal tomato necrosis unless challenged with CMV (McGarvey et al., 1990), while a recent report by Saito et al. (1992) suggests that a mild variant will induce tolerance to CMV.

In this paper we present a more comprehensive analysis of the protective effects of an attenuating CMV satellite variant in transgenic tomato plants against subsequent challenge infections with CMV and the related cucumovirus tomato aspermy virus (TAV).

\section{Materials and Methods.}

Plant transformation. Monomeric cDNA clones of the attenuating CMV satellite CMV associated RNA 5 from CMV strain S (S-CARNA 5) (Collmer and Kaper, 1986) were inserted into the binary vector RG-2 (Fig. 1). RG-2 is a Bin 19 derivative similar to pBI121 (Jefferson, 1990). Recombinant plasmids containing the satellite insert and the RG-2 vector [containing $\beta$-glucuronidase (GUS) alone] were engineered into Agrobacterium tumefaciens and inserted into two varieties of tomato, UC82b (Petoseed, Saticoy, Calif.) and an Asian variety CL143 (provided by R.T. Opena, AVRDC, Taiwan) by A. tumefaciens infection of cotyledons, which were regenerated into plants using a modification of the methods of Fillatti et al. (1987) and McCormick (1991). Putative transgenic plants were screened for inserted DNA by the polymerase chain reaction (PCR) (McGarvey and Kaper, 1991) and by southern blot hybridization (Maniatis et al., 1982), and for RNA expression by northern blot hybridization of RNA (see below). GUS expression was tested by a histochemical assay (Jefferson, 1990).

Challenge inoculations. Isolates of CMV-1 and TAV, free of satellite RNA, were used to infect transgenic tomato plants and control plants. CMV-1 (Kaper et al., 1981) produces symptoms of severe shoestring leaves, chlorosis, and stunting in tomato. TAV 


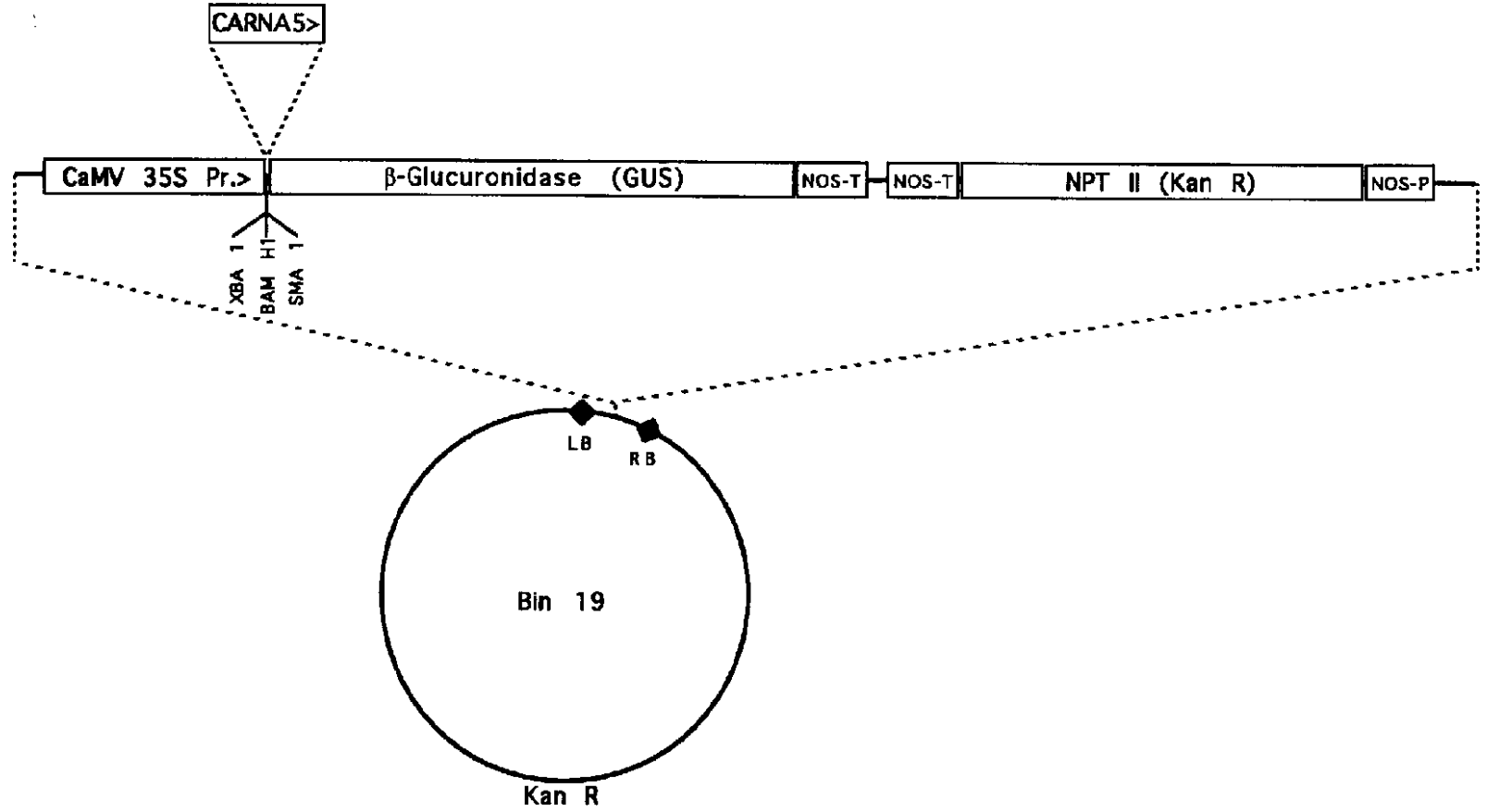

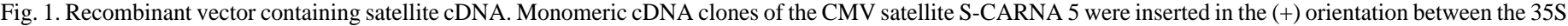

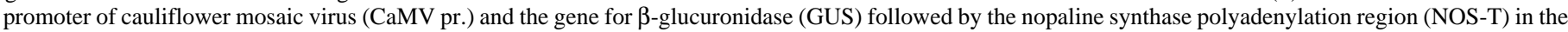

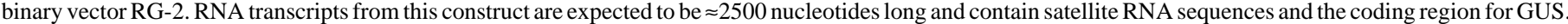
The NPTII gene provides kanamycin resistance (KanR) in plants.

was a Canadian isolate (Stace-Smith and Tremaine, 1973) and produces stunting, mild chlorosis, leaf puckering, and a reduction in apical dominance in tomato. Virions were purified from infected tomato plants and viral RNA was extracted as described (Kaper and West, 1972; Lot et al., 1972). Plants were mechanically inoculated at the cotyledon stage using RNA at $10 \mu \mathrm{g} \cdot \mathrm{ml}^{-1}$ in 0.03 $\mathrm{M} \mathrm{Na} \mathrm{HPO}_{4}$ or virions at $20 \mu \mathrm{g} \cdot \mathrm{ml}^{-1}$ in water. Purified S-CARNA 5 at $2.5 \mu \mathrm{g} \cdot \mathrm{ml}^{-1}$ was added in some positive control infections. Plants were kept in growth chambers at $24 \mathrm{C}$ with a 16 -h photoperiod using fluorescent light at $150 \mu \mathrm{E} \cdot \mathrm{m}^{-2} \cdot \mathrm{s}^{-1}$. CMV -1 . A total of 16 $\mathrm{R}_{1}$ transgenic seedlings from a single UC82b-derived $\mathrm{R}_{0}$ plant (designated UC47-2) were challenge-inoculated with CMV-1 RNA, and 10 similar seedlings were inoculated with CMV-1 virions. Six transgenic seedlings were mock-inoculated with buffer. Four $\mathrm{R}_{1}$ seedlings derived from a separate $\mathrm{R}_{0}$, UC82b-derived transgenic parent (designated UC47-6) were challenged with CMV-1 RNA, as were eight $R_{1}$ seedlings derived from a transgenic CL143 $\mathrm{R}_{0}$ parent (designated 0110-1). Two each of the UC47-6 and 0110-1 progeny were mock-inoculated. As controls, nontransformed UC82b and CL143 seedlings were inoculated as follows: seven UC82b and three CL143 with CMV-1 RNA, four UC82b with CMV-1 virions, seven UC82b and three C1143 with CMV-1 RNA plus S-CARNA 5, and eight UC82b and two C1143 were mock-inoculated. As additional controls, eight $\mathrm{R}_{1}, \mathrm{UC} 82 \mathrm{~b}$-derived transgenic plants containing the RG-2 vector without the satellite RNA insert but with the GUS gene (designated UCRG2-1) were inoculated with CMV-1 RNA and four with CMV-1 virions as controls.

$T A V$. Four UC47-2-derived and four UC47-6-derived $\mathrm{R}_{1}$ seedlings were inoculated with TAV RNA. As controls, eight nontransformed UC82b seedlings were inoculated with TAV RNA and six with TAV RNA plus S-CARNA 5. In addition, four UCRG2-1 transgenic seedlings were inoculated with TAV RNA as controls.

Nucleic acid extraction and northern blot hybridizations. Leaf
RNA was extracted using a total RNA isolation kit (Promega, Madison, Wis.). Poly(A)-enriched RNA was prepared from total RNA using a Poly(A) Quik kit (Stratagene, La Jolla, Calif.). Poly(A)-enriched RNA was electrophoresed through $1.5 \%$ agarose-formaldehyde gels and transferred to nylon membranes (Maniatis et al. 1982). Total nucleic acids were prepared from all challenged plants and controls using $100 \mathrm{mg}$ young leaf tissue, electrophoresed through a $9 \%$ semi-denaturing polyacrylamide gel, and electrotransferred to nylon membranes as described (White and Kaper, 1989). All membranes were hybridized, washed, and visualized using standard procedures. S-CARNA 5 and CMV RNA 4 sequences were detected using ${ }^{32} \mathrm{P}$-labeled riboprobes from cDNA inserts in the plasmid pSP65 (Promega). TAV RNA was detected using a cDNA probe made from randomly primed TAV RNA (Maniatis et al., 1982).

Symptom scoring and analysis. Plants were evaluated for disease symptoms at 2, 3, and 4 weeks after challenge inoculations and assigned a score of $0=$ symptomless; $1=$ mild chlorosis; $2=$ full chlorosis or mild chlorosis plus mild shoestring leaves; $3=$ shoestring leaves or other leaf or stem malformations; and $4=$ severe stunting plus any combination of other symptoms. Evaluation was made without knowledge of the inoculum used or the plants' status as transgenic or control. Disease intensity for a particular treatment was calculated by the formula $\mathrm{DI}=\left[\sum(\mathrm{s} \times \mathrm{n}) /\right.$ $\mathrm{S} \times \mathrm{N}] \times 100 \%$, where $\mathrm{s}=$ score of 0 to $4, \mathrm{n}=$ number of plants with a particular numerical score, $\mathrm{S}=$ highest possible score, and $\mathrm{N}=$ total number of plants. Challenged plants that showed no viral infection by northern blot analysis or enzyme-linked immunosorbent assay (ELISA) were omitted from the final analysis as were $\mathrm{R}_{1}$ plants that did not show the presence of the recombinant DNA insert as determined by PCR.

Serological detection of virus. ELISA was used to test for the presence of CMV in challenged plants. Tissue was collected 4 weeks after challenge and frozen at $-70 \mathrm{C}$. Tissue was later ex- 
tracted and ELISA was performed as described (Clark and Adams, 1977; Montasser et al., 1991), except that multiple dilutions of each sample were used and a dilution series of the purified CMV1 virions was included as a standard. Statistical analysis was performed using Student's $t$ test. Challenged plants that showed no sign of viral infection by northern blot hybridization or ELISA were omitted from the final analysis.

\section{Results}

Plant transformation. After transformation, two UC82b-derived (designated UC47-2 and UC47-6) and six Cl143-derived (designated $0110-1$ to 6 ) primary $\left(R_{0}\right)$ transgenic plants were obtained. In morphology and fruiting behavior, the plants were essentially identical to nontransformed plants regenerated from tissue culture. The $\mathrm{R}_{1}$ generation seeds germinated in soil and developed like the control seedlings. Expression of the cDNA insert in the $\mathrm{R}_{0}$ transformed plants was determined by northern blot analysis, which showed an RNA transcript of $\approx 2.5 \mathrm{~kb}$ (Fig. 2), and by assaying for GUS activity, which was present in the transgenic plants and absent in controls (not shown). PCR screening of the $\mathrm{R}_{1}$ progeny showed that 41 of 51 UC47-2 progeny contained the gene, consistent with the 3:1 segregation ratio expected from a single insert in the primary transgenic plant $\left(\chi^{2}=0.79\right)$. The segregation ratio of the UC47-6 and 0110-1 offspring also suggested a single insert, but the numbers screened were insufficient for a final determination.

$C M V-1$ challenge. All 26 of the UC47-2 progeny challenged with either CMV-1 RNA or virions became infected with CMV-1. Twelve of the plants challenged with CMV-1 RNA and six plants challenged with virions showed the accumulation of single-stranded (ss) and double-stranded (ds) S-CARNA 5 (Fig. 2, lane 3; Fig. 3 a and b). S-CARNA 5 was observed only in plants that contained the transgenic satellite insert. Of the eight remaining offspring challenged with CMV-1, but in which no ss or ds S-CARNA 5 accumulated, five did not contain the recombinant insert, while

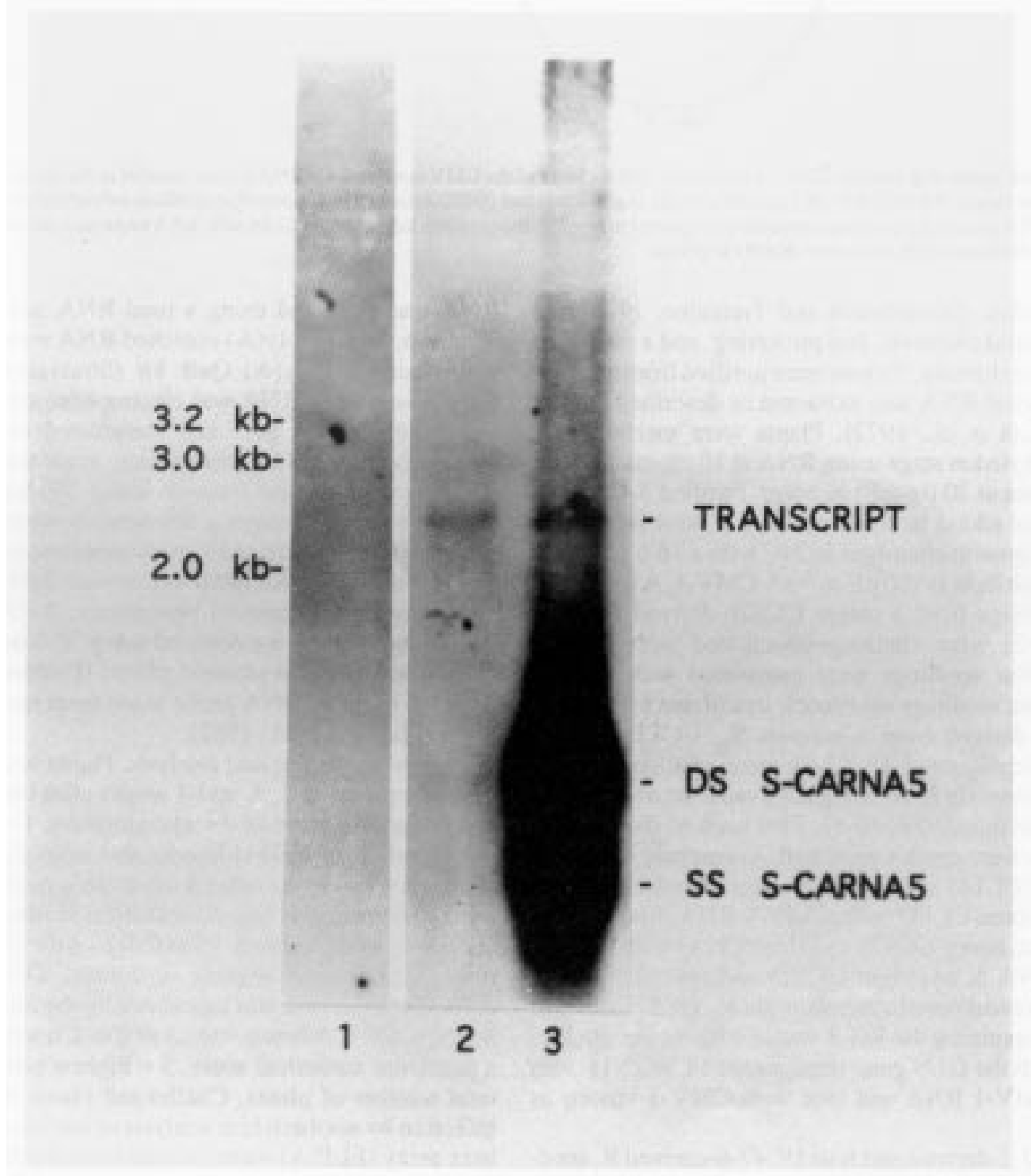

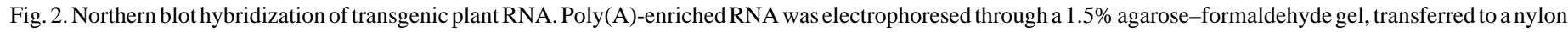

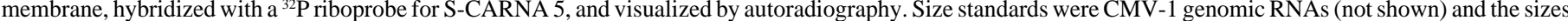

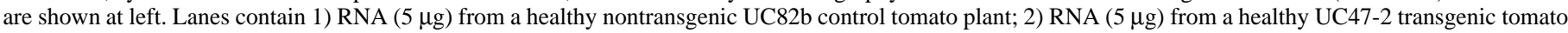

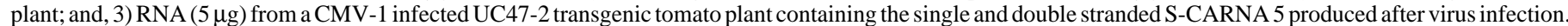
Note that poly(A)-enriched RNA is $\approx 90 \%$ poly(A) RNA and, thus, still contains some mature satellite RNA. 


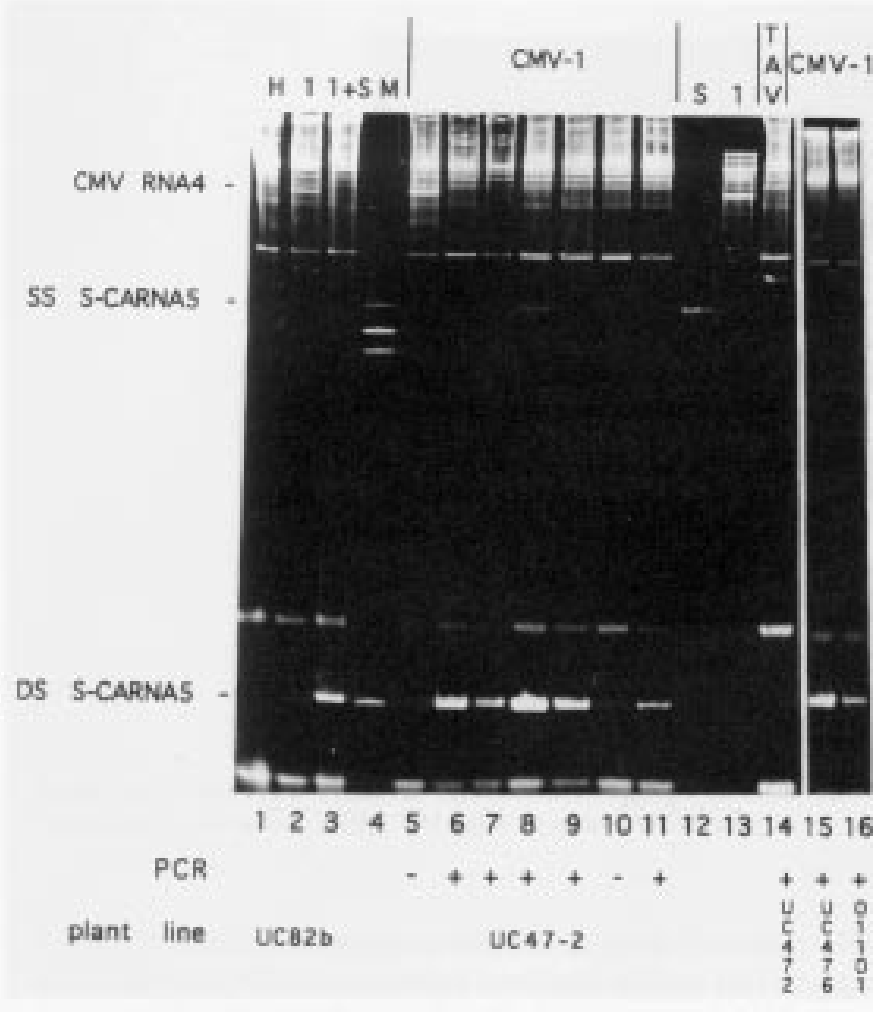

Fig. 3a. Semidenaturing electrophoresis of RNA from challenge-inoculated plants Lanes contain RNA from 1) healthy nontransgenic UC82b tomato;2) nontransgenic UC82b tomato infected with CMV-1 RNA; 3) same as lane 2 infected with CMV1 and S-CARNA 5; 4) satellite RNA markers, (top to bottom) single-stranded PARNA 5, 1-CARNA 5, n-CARNA 5, and double stranded D-CARNA 5; 5-11) individual tomato plants from the $\mathrm{R}_{1}$ generation of the UC47-2 transgenic plant that were all challenge-inoculated with CMV-1 RNA; 12) gel-purified S-CARNA 5 ; 13) CMV-1 RNA ( $1 \mu \mathrm{g}$ ) used as inoculum; 14 ) transgenic tomato plant (UC472 line) challenged with TAV RNA; 15) transgenic tomato plant (UC47-6 line) challenged with CMV-1 RNA; and 16) transgenic tomato plant (0110-1 line) challenged with CMV-1 RNA. The presence or absence of the recombinant DNA insert in the individual offspring was determined by polymerase chain reaction and is indicated by a (+) or (-) at the bottom.

three of the plants challenged with virions did. The disease symptoms were scored, expressed as disease intensity, and are shown in Fig. 4. During the first 2 weeks, there were only small differences between the transgenic and control groups with most plants showing some mild chlorosis. However, by the third and fourth weeks, the systemic spread of viral disease seemed to stop and disease symptoms receded dramatically in the transgenic group until there was little obvious difference between challenged transgenic plants and the mock-inoculated transgenic and control plants, except for some mild chlorosis on the older leaves of some transgenic plants (Fig. 5). The transgenic offspring that lacked the recombinant insert showed no symptom attenuation and were similar in appearance to the CMV-1-infected UC82b controls and the CMV-1-infected transgenic controls containing the RG-2 vector alone. ELISA showed a significant difference in virus titer between the transgenic group challenged with CMV-1 RNA and the control group, with averages of $31.6(\sigma \pm 24.5) \mu \mathrm{g} \cdot \mathrm{g}^{-1}$ and 355.0 $(\sigma \pm 15.8) \mu \mathrm{g} \cdot \mathrm{g}^{-1}(P=0.01)$ tissue, respectively. A similar result was obtained in the groups challenged with virions: transgenic $=$ $31.5(\sigma \pm 14.1) \mu \mathrm{g} \cdot \mathrm{g}^{-1} ;$ control $=500.0(\sigma \pm 178.0) \mu \mathrm{g} \cdot \mathrm{g}^{-1}(P=$ $0.005)$. The five transgenic offspring that did not contain the recombinant insert had a average virus titer of $370.0(\sigma \pm 95.0)$ $\mu \mathrm{g} \cdot \mathrm{g}^{-1}$ tissue and the RG-2-containing transgenic control plants had an average virus titer of $398.0(\sigma \pm 97.1) \mu \mathrm{g} \cdot \mathrm{g}^{-1}$ tissue.

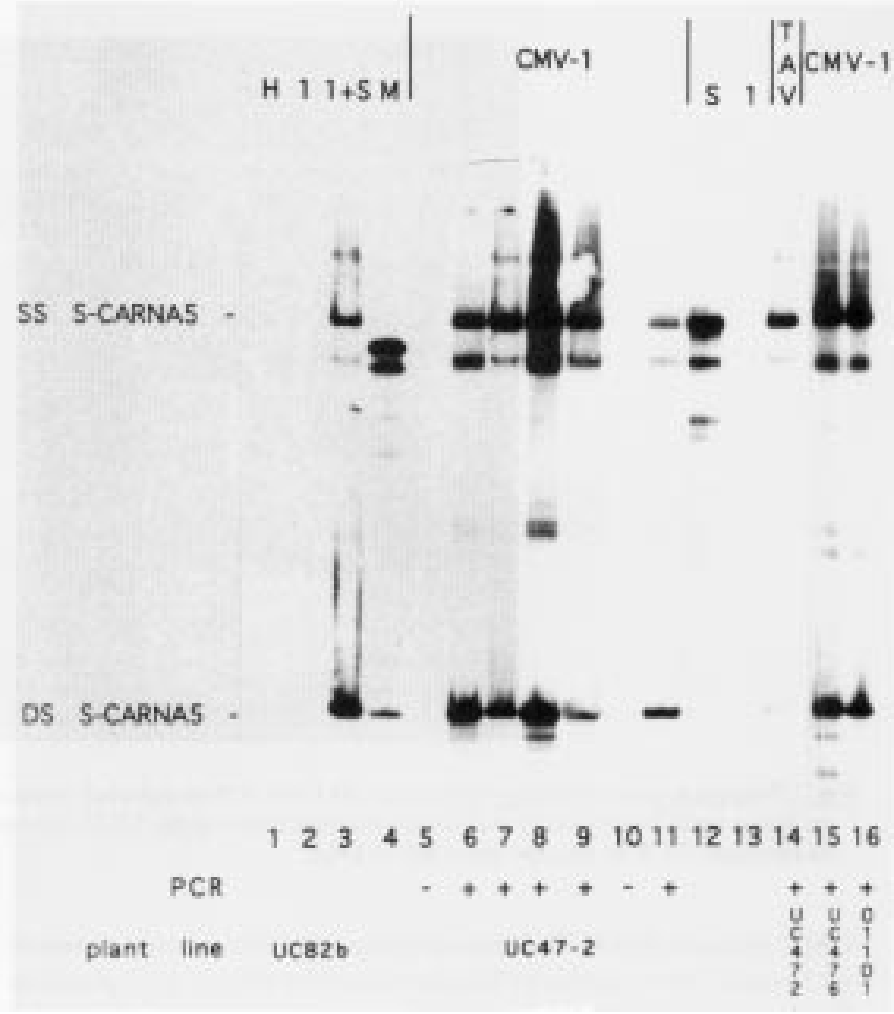

Fig. 3b. Northern blot hybridization of RNA from challenge-inoculated plants. Lanes are the same as (a). Note that PARNA 5 does not hybridize with S-CARNA 5 and that single-stranded S-CARNA 5 often migrates as two conformational isomers in semidenaturing gels and a second band immediately below the main band in the single-stranded region is observed in lane 13 and lanes 5-11 and 14 16. The two bands have been gel-purified, sequenced, and are both S-CARNA 5 (H. Sayama, personal communication).

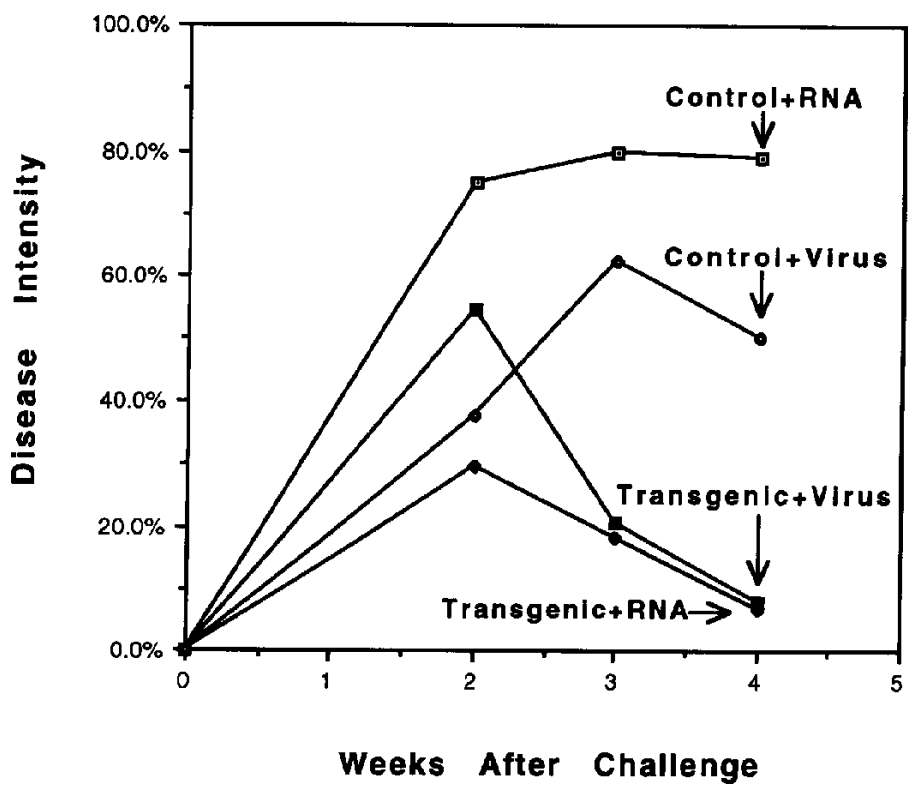

Fig. 4. Disease intensity of challenged plants. Transgenic (UC47-2) and normal (UC82b) tomato seedlings were inoculated with CMV-1 RNA or CMV-1 virions. Plants were evaluated and disease index was calculated as described in Materials and Methods.

All of the UC47-6 and 0110-1 progeny were infected with CMV-1 RNA. Two of the UC47-6 and six of the 0110-1 plants contained the satellite insert and showed accumulation of ss and ds S-CARNA 5 (Fig. $3 \mathrm{a}$ and b, lanes 15 and 16) and a reduction in 


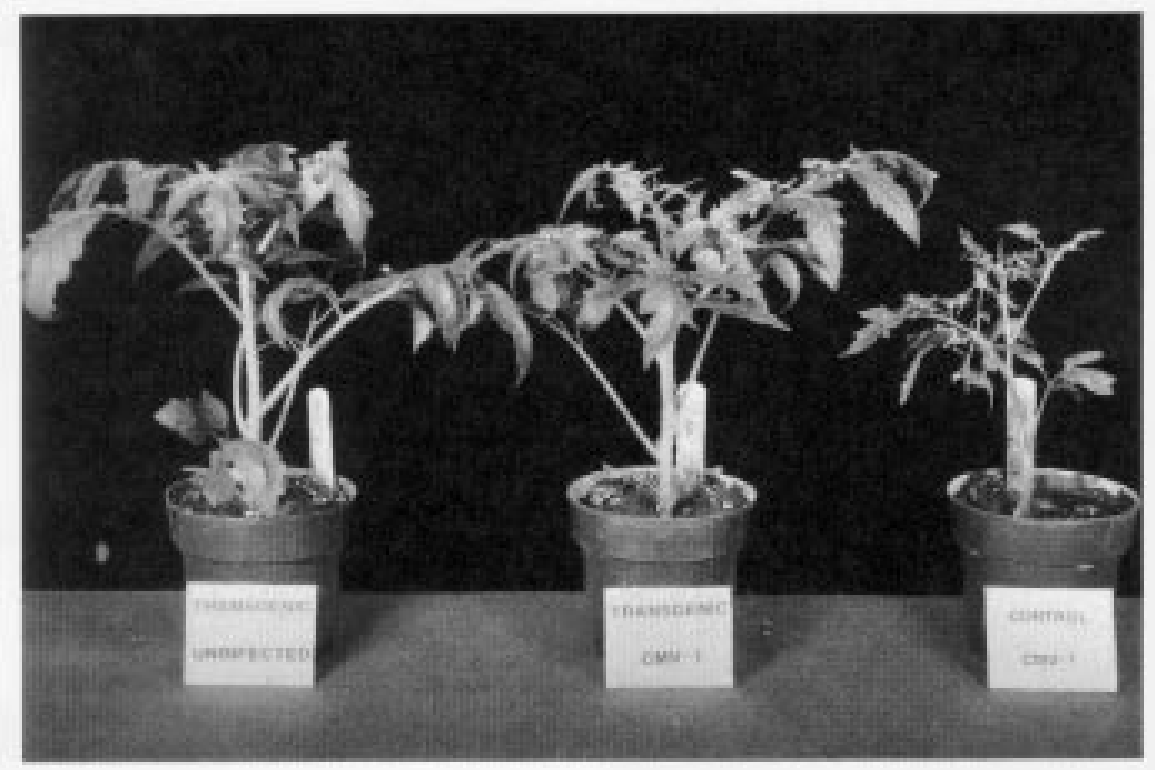

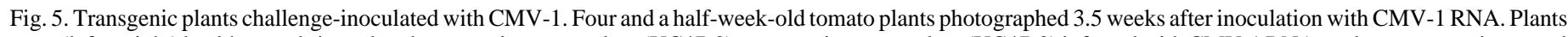

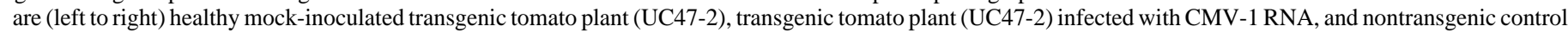
tomato plant (UC82b) infected with CMV-1 RNA.

CMV genomic RNA. The disease symptoms were scored as above with results very similar to that described for the UC47-2 plants in Fig. 4, with mild CMV-1 symptoms appearing during the first 2 weeks but receding dramatically during the next 2 weeks (data not shown). ELISA showed the presence of virus but was not quantified.

TAV RNA challenge. Three of four 47-2 and three of four 47-6 transgenic offspring became infected with TAV. All six of the infected plants contained the recombinant insert but only five of the six showed the presence of ss and ds S-CARNA 5. In each case, ds S-CARNA 5 did not accumulate to the amounts typical of the CMV infections (Fig. 3 a and b, lane 14). Little to no reduction in the accumulation of TAV RNA was observed in plants in which satellite RNA was found (not shown). Equally strong TAV symptoms were observed in the transgenic and control plants, regardless of whether satellite RNA accumulated or not.

\section{Discussion}

The results of the challenge infections with CMV-1 clearly show that transgenic tomato plants expressing an attenuating satellite RNA sequence have improved tolerance to CMV-induced disease (Figs. 4 and 5), probably as a result of about a 10-fold reduction in virus titer. This result had been predicted after our previous tomato transformation with a necrogenic satellite (McGarvey et al., 1990), and was recently also reported by Saito et al. (1992), who described their transformation of tomato plants expressing an attenuating satellite and showed preliminary data on $\mathrm{R}_{0}$ plant tolerance to CMV-O infection. In the more comprehensive analysis presented here, this tolerance was quantified with measurements of disease intensity and virus titer in $\mathrm{R}_{1}$ plants of two tomato varieties. Further, it was shown that tolerance holds for virion and RNA challenges, and the analysis was extended to TAV and other virus strains (see below). The practical importance of this result is that CMV satellite-mediated tolerance can be engineered into tomato for which, to date, no naturally resistant varieties have been found (Phills et al., 1977; Stamova et al., 1990). In addition, since the inserted satellite sequences lie embedded in a much larger
RNA transcript that also encodes an expressed protein (GUS), it suggests that satellite-mediated tolerance could be combined in a single RNA transcript with other forms of protection that require protein expression. However, any quantitative effects on protein expression remain to be determined. In tobacco, a combination of satellite and coat protein protection using separate promoters for the individual genes has recently been reported to provide increased levels of tolerance to CMV infection (Yie et al., 1992).

The lack of symptom attenuation in TAV challenge infections is different from the reduction in symptoms reported for satellite transgenic tobacco (Harrison et al., 1987). In addition, when transgenic tomato plants expressing the necrogenic satellite DCARNA 5 (McGarvey et al., 1990) were challenged with TAV, no necrosis or other symptom modulation was observed (unpublished data), although unit-length satellite accumulated in a manner similar to that seen for S-CARNA 5 (Fig. $3 \mathrm{a}$ and b, lane 14) with a proportionately lower amount of ds D-CARNA 5. Similarly, control inoculations of nontransgenic UC82b tomato plants with S-CARNA 5 or D-CARNA 5 with TAV as a helper virus failed to modulate the symptoms of the TAV isolate used in our experiments. Moriones et al. (1992) have also reported differences in symptom modulation and CMV satellite accumulation between two different isolates of TAV and noticed a proportional decrease in the accumulation of the ds satellite with TAV infections compared to CMV infections. That lower ds/ss CARNA 5 proportions may relate to a failure in eliciting tomato necrosis has been shown for the Ixora strain of CMV (Kaper et al., 1990b). All this suggests that differences in the response of satellite-transgenic plants to infections by TAV and CMV strains may depend on qualitative and quantitative differences in satellite vs. virus replication, which in turn determines the ultimate biological effect.

Challenges of UC47-2-, UC47-6-, and 0110-1-derived transgenic plants using CMV-S and CMV-D also showed the accumulation of ss and ds S-CARNA 5 and a reduction in symptoms by the fourth week postchallenge (unpublished results). However, the engineered tolerance should not be assumed to extend to all CMV isolates until further testing of a wide variety of CMV isolates, including isolates containing their own satellite RNAs, is completed. 


\section{Literature Cited}

Baulcombe, D.C., G.R. Saunders, M.W. Bevan, M.A. Mayo, and B.D. Harrison. 1986. Expression of biologically active viral satellite RNA from the nuclear genome of transformed plants. Nature 321:446-449.

Clark, M.F. and A.N. Adams. 1977. Characteristics of the microplate method of enzyme-linked immunosorbent assay for the detection of plant viruses. J. Gen. Virol. 34:475-483.

Collmer, C.W. and S.H. Howell. 1992. Role of satellite RNA in the expression of symptoms caused by plant viruses. Annu. Rev. Phytopathol. 30:419-442.

Collmer, C.W. and J.M. Kaper. 1986. Infectious RNA transcripts from cloned cDNAs of cucumber mosaic viral satellites. Biochem. Biophys. Res. Commun. 135:290-296.

Daniels, J. and R.N. Campbell. 1992. Characterization of cucumber mosaic virus isolates from California. Plant Dis. 76:1245-1250.

Davis, R.F. and O. Shifriss. 1983. Natural virus infection in silvery and nonsilvery lines of Cucurbita pepo. Plant Dis. 67(4):379-380.

Fillatti, J.J., J. Kiser, R. Rose, and L. Comai. 1987. Efficient transfer of a glyphosate tolerance gene into tomato using a binary Agrobacterium tumefaciens vector. Bio/Technology 5:726-730.

Gallitelli, D., A. DiFranco, and C. Vovlas. 1988. Epidemie del virus del mosaico del cetriolo e di potyvirus in Italia meridionale repertorio dei virus e aspetti ecologici. L'Informatore Agrario 44:40-45.

Gallitelli, D., C. Vovlas, G.P. Martelli, M.S. Montasser, M.E. Tousignant, and J.M. Kaper. 1991. Satellite-mediated protection of tomato against cucumber mosaic virus. II. Field test under natural epidemic conditions in Southern Italy. Plant Dis. 75:93-95.

Gonsalves, D., R. Provvidenti, and M.C. Edwards. 1982. Tomato whiteleaf: The relation of an apparent satellite RNA and cucumber mosaic virus. Phytopathology 72:1533-1538.

Harrison, B.D., M.A. Mayo, and D.C. Baulcombe. 1987. Virus resistance in transgenic plants that express cucumber mosaic virus satellite RNA. Nature 328:799-802.

Jacquemond, M., J. Amselem, and M. Tepfer. 1988. A gene coding for a monomeric form of cucumber mosaic virus satellite RNA confers tolerance to CMV. Mol. Plant-Microbe Interactions 1:311-316.

Jefferson, R. 1990. GUS gene fusion system user's manual. Clontech Labs, Palo Alto, Calif.

Jorda, C., A. Alfaro, M.A. Aranda, E. Moriones, and F. Garcia-Arenal. 1992. An epidemic of cucumber mosaic virus plus satellite RNA in tomatoes in eastern Spain. Plant Dis. 76:363-366.

Kaper, J.M. and C.W. Collmer. 1988. Modulation of viral plant diseases by secondary RNA agents, p. 171-194. In: E. Domingo, J. Holland, and P. Ahlquist (eds.). RNA genetics. Vol. III: Variability of RNA genomes. CRC Press., Boca Raton, Fla.

Kaper, J.M., D. Gallitelli, and M.E. Tousignant. 1990a. Identification of a 334-ribonucleotide viral satellite as principal aetiological agent in a tomato necrosis epidemic. Res. Virol. 141:81-95.

Kaper, J.M., M.E. Tousignant, and L.M. Geletka. 1990b. Cucumber mosaic virus-associated RNA 5. XII. Symptom modulating effect is codetermined by satellite replication support function of helper virus. Res. Virol. 141:487-503.

Kaper, J.M., M.E. Tousignant, and S.M. Thompson. 1981. Cucumber mosaic virus-associated RNA 5. VIII. Identification and partial characterization of a CARNA 5 incapable of inducing tomato necrosis. Virology 114:526-533.

Kaper, J.M. and C.K. West. 1972. Polyacrylamide gel separation and molecular weight determination of the components of cucumber mosaic virus RNA. Preparative Biochem. 2:251-263.

Kearney, C.M., T.A. Zitter, and D. Gonsalves. 1990. A field survey for serogroups and satellite RNA of cucumber mosaic virus. Phytopathol- ogy 80:1238-1243.

Lot, H., J. Marrou, J.B. Quiot, and Ch. Esvan. 1972. Contribution à l'étude du virus de la mosaïque du concombre (CMV). II. Méthode de purification rapide du virus. Ann. Phytopathol. 4:25-38.

Maniatis, T., E.F. Fritsch, and J. Sambrook. 1982. Molecular cloning: A laboratory manual. Cold Spring Harbor Laboratory, Cold Spring Harbor, N.Y.

Marrou, J. and H. Duteil. 1974. La nécrose de la tomate. Ann. Phytopathol. 6:155-171.

Masuta, C., T. Komari, and Y. Takanami. 1989. Expression of cucumber mosaic virus satellite RNA from cDNA copies in transgenic tobacco plants. Ann. Phytopathol. Soc. Jpn. 55:49-55.

McCormick, S. 1991. Plant tissue culture manual. Kluwer Acad. Publ., Dordrecht, The Netherlands.

McGarvey, P.B. and J.M. Kaper. 1991. A simple and rapid method for screening transgenic plants using the polymerase chain reaction. BioTechniques 11:428-432.

McGarvey, P.B., J.M. Kaper, M.J. Avila-Rincon, L. Peña, and J.R. DiazRuiz. 1990. Transformed tomato plants express a satellite RNA of cucumber mosaic virus and produce lethal necrosis upon infection with viral RNA. Biochem. Biophys. Res. Commun. 170:548-555.

Montasser, M.S., M.E. Tousignant, and J.M. Kaper. 1991. Satellitemediated protection of tomato against cucumber mosaic virus. I. Greenhouse experiments and simulated epidemic conditions in the field. Plant Dis. 75:86-92.

Moriones, E., I. Diaz, E. Rodriguez-Cerezo, A. Fraile, and F. GarciaArenal. 1992. Differential interactions among strains of tomato aspermy virus and satellite RNAs of cucumber mosaic virus. Virology 186:475480.

Phills, B.R., R. Provvidenti, and R.W. Robinson. 1977. Reaction of Solanum lycopersicoides to viral diseases of the tomato. Tomato Genet. Coop. Rpt. 27:18.

Roossinck, M.J., D. Sleat, and P. Palukaitis. 1992. Satellite RNAs of plant viruses: Structures and biological effects. Microbiol. Rev. 56:265-279.

Saito, Y., T. Komari, C. Masuta, Y. Hayashi, T. Kumashiro, and Y. Takanami. 1992. Cucumber mosaic virus-tolerant transgenic tomato plants expressing a satellite RNA. Theoretical Applied Genet. 83:679_ 683.

Sayama, H., T. Sato, M. Kominato, T. Natsuaki, and J.M. Kaper. 1993 Field testing of a satellite-containing attenuated strain of cucumber mosaic virus for tomato protection in Japan. Phytopathology 83:405410

Stace-Smith, R. and J.H. Tremaine. 1973. Biophysical and biochemical properties of tomato aspermy virus. Virology 51:401-408.

Stamova, L., D. Christova, and M. Yordanov. 1990. Resistance to cucumber mosaic virus (CMV). Tomato Genet. Coop. Rpt. 40:33-34.

Tien, P. and G-S. Wu. 1991. Satellite RNA for the biological control of plant disease, p. 321-339. In: K. Maramorosch, F. Murphy, and A. Shatkin (eds.). Advances in virus research. vol. 39. Academic Press, New York.

Tien, P., X-H. Zhang, B-S. Qiu, B. Qin, and G-S. Wu. 1987. Satellite RNA for the control of plant diseases caused by cucumber mosaic virus. Ann. Applied Biol. 111:143-152.

Tomlinson, J.A. 1987. Epidemiology and control of virus diseases of vegetables. Ann. Applied Biol. 110:661-681.

White, J.L. and J.M. Kaper. 1989. A simple method for detection of viral satellite RNAs in small plant tissue samples. J. Virol. Methods 23:8394.

Yie, Y., F. Zhao, S.Z. Zhao, Y.Z. Liu, Y.L. Liu, and P. Tien. 1992. High resistance to cucumber mosaic virus conferred by satellite RNA and coat protein in transgenic commercial tobacco cultivar G-140. Mol. PlantMicrobe Interactions 5:460-465. 